\title{
Implementation of the protocol of nursing care in trauma in aeromedical service
}

\author{
Implementação do protocolo de cuidados de enfermagem no trauma em serviço aeromédico \\ Implementación del protocolo de la atención de enfermería en el trauma en servicio aeromédico
}

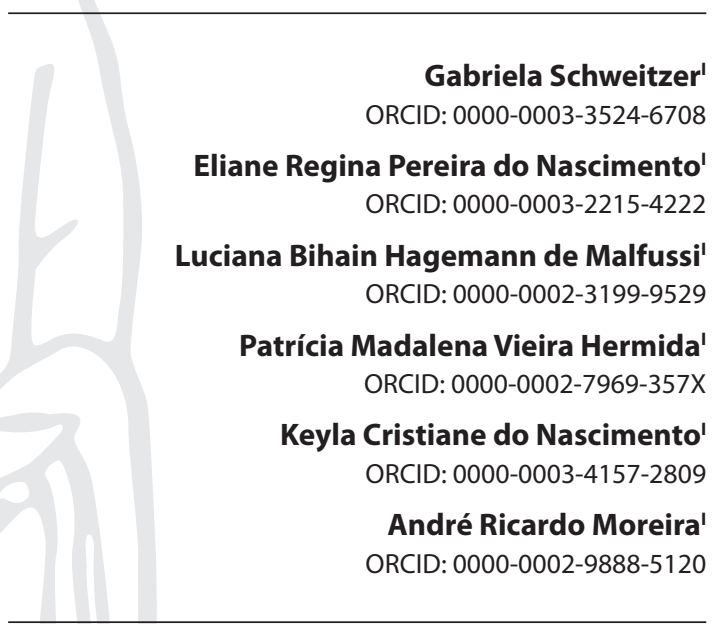

'Universidade Federal de Santa Catarina. Florianópolis, Santa Catarina, Brazil.

How to cite this article: Schweitzer G, Nascimento ERP, Malfussi LBH, Hermida PMV Nascimento KC, Moreira AR. Implementation of the protocol of nursing care in trauma in aeromedical service. Rev Bras Enferm. 2020;73(3):e20180516. doi: http://dx.doi.org/10.1590/0034-7167-2018-0516

\section{Corresponding author: Gabriela Schweitzer E-mail: gabyschw@hotmail.com}

EDITOR IN CHIEF: Dulce Aparecida Barbosa ASSOCIATE EDITOR: Marcia Magro

Submission: 06-07-2018

Approval: 05-11-2019

\begin{abstract}
Objective: To analyze the implementation of a nursing care protocol for trauma patients before, during and after the flight. Method: A cross-sectional quantitative study carried out in an aeromedical service, using a checklist with 106 care: 79 before flight, 25 during, and 2 after flight. 97 patients were included in the study. Results: Most care $(n=59 ; 55.7 \%)$ was implemented, totaling 4,435, 1,480 and 192 cares performed before, during and after the flight, respectively. They stood out as unrealized care: protect ears with ear muffler $(n=55)$ and avoid leaving the pulse oximeter exposed to the sun's rays $(n=22)$. The main reason for the non-performance was lack of appeal $(n=94)$. Conclusion: Although most protocol care has been implemented, unrealized care compromises the quality of care, which requires the management of the service to provide more incentive to nurses and adequate resources for its implementation.
\end{abstract}

Descriptors: Nursing Assessment; Advanced Trauma Life Support Care, Aerospace Medicine Emergency Medical Services, Emergency Nursing.

\section{RESUMO}

Objetivo: analisar a implementação de um protocolo de cuidados de enfermagem para pacientes com trauma, antes, durante e após o voo. Método: estudo quantitativo, transversal, realizado em um serviço aeromédico, mediante aplicação de um checklist com 106 cuidados: 79 antes do voo, 25 durante, e dois após o voo. Resultados: a maioria dos cuidados ( $n=59$; $55,7 \%$ ) foi implementada, totalizando 4.435, 1.480 e 192 cuidados realizados antes, durante e após o voo. Destacaram-se como cuidados não realizados: proteger ouvidos com abafador de orelha $(n=55)$ e evitar deixar o oxímetro de pulso exposto a raios solares $(n=22)$. 0 principal motivo da inexecução foi falta de recurso $(n=94)$. Conclusão: embora a maioria dos cuidados do protocolo tenha sido implementada, os cuidados não realizados comprometem a qualidade da assistência, o que requer da gestão do serviço maior incentivo aos enfermeiros e recursos adequados para sua efetivação.

Descritores: Protocolos; Cuidados de Suporte Avançado de Vida no Trauma; Medicina Aeroespacial; Serviços Médicos de Emergência; Enfermagem em Emergência.

\section{RESUMEN}

Objetivo: Evaluar la implementación de un protocolo de atención de enfermería a pacientes traumatizados antes, durante y después del vuelo. Método: Estudio cuantitativo, transversal, realizado en un servicio aeromédico mediante la aplicación de un checklist con 106 cuidados: 79 antes del vuelo, 25 durante, y 2 después del vuelo. Compusieron la muestra 97 pacientes. Resultados: Se implementó la mayoría $(n=59 ; 55,7 \%)$, y totalizaron 4.435 cuidados realizados antes del vuelo; 1.480 realizados durante; y 192 cuidados realizados después del vuelo. Se destacaron como cuidados no realizados: proteger oídos con orejera $(n=55)$ y evitar dejar el oxímetro de pulso expuesto a rayos solares $(n=22)$. El principal motivo de la no ejecución fue la falta de recurso $(n=94)$. Conclusión: Aunque la mayoría de los cuidados han sido implementados, los cuidados no realizados comprometen la calidad de la asistencia, lo que requiere que la gestión del servicio incentive a los enfermeros y ofrezca recursos adecuados para efectivarla.

Descriptores: Evaluación en Enfermería; Atención de Apoyo Vital Avanzado en Trauma; Medicina Aeroespacial; Servicios Médicos de Urgencia; Enfermería de Urgencia. 
Implementation of the protocol of nursing care in trauma in aeromedical service Schweitzer G, Nascimento ERP, Malfussi LBH, Hermida PMV, Nascimento KC, Moreira AR.

\section{INTRODUCTION}

The construction and implementation of clinical protocols should be understood as a theoretical and practical support tool, contributing to the planning and evaluation of care and, consequently, to quality of care $^{(1)}$. The adoption of protocols supported and defined based on the best scientific evidence contributes to more positive health outcomes, as well as to accompany the growing technological incorporation in health care ${ }^{(2-3)}$, such as air rescue in pre-hospital care with the use of helicopters in remote locations.

Air transport requires health professionals to understand the physiology and changes that may occur in the patient. This knowledge should be the basis of the specific abilities to perform in the aerospace environment, both in fixed-wing aircraft, as airplanes, and rotary-wing, the helicopters ${ }^{(4)}$. In the case of trauma, the need for procedures to prevent or correct physiological irregularities should be considered so that emergency interventions are executed by an aeromedical service ${ }^{(5)}$.

Due to the particularities of this service, a nursing care protocol specific to the aerospace environment was developed, together with the nurses of the Emergency Response Group (Grau) of the Mobile Emergency Care Service (Samu) of Santa Catarina, intended for traumatized adult patients. This protocol, which was the object of this study, was validated ${ }^{(6)}$ to provide a rapid and systematized reading of care, as to stimulate its use by nurses.

Clinical protocols are increasingly being developed, which does not mean that they are automatically implemented ${ }^{(7)}$, since their application in clinical practice implies effective communication strategies, identifying and overcoming specific difficulties or barriers in the local context ${ }^{(2)}$. Among the factors that influence the implementation of protocols, one can be cited as barriers: time constraints; limited staff resources; and knowledge about the protocol. Facilitators include: protocol characteristics (format, resources and end-user involvement); involvement of stakeholders; organizational culture; and electronic protocol systems ${ }^{(8)}$. Patient characteristics also seem to influence, such as comorbidity, which reduces the chance the protocol will be followed ${ }^{(7)}$. Thus, for an effective implementation of protocols for patients with trauma, their characteristics must be considered, in addition to identification and overcoming the factors that negatively interfere with their application.

In this meander, the assistance protocols provide for the definition of a specific situation of assistence or care, describing details about the operational actions and specifications about the mode of execution and the professional executor. Thus, the protocols are justified because they are instruments that reduce the variability of conduct among professionals involved in health care, favor greater patient and professional safety, besides allowing the elaboration of process and results indicators, improving the quality of assistance ${ }^{(9-10)}$.

In view of the above, and considering the need for aeromedical rescue studies in the country, which does not have an organized trauma care system ${ }^{(11)}$, this study is justified by providing subsidies for flight nurse assistance and improving the quality of care.

\section{OBJECTIVE}

To analyze the implementation of a nursing care protocol for patients with trauma in an aeromedical service in Santa Catarina.

\section{METHOD}

\section{Ethical aspects}

Study approved by the Research Ethics Committee of the Federal University of Santa Catarina (CEPSH-UFSC). Data collection started after presentation of the study and signing of the Informed Consent Form (ICF) by the participants.

\section{Study design, location and period}

A quantitative, cross-sectional study carried out from October 2013 to May 2014 with the aeromedical service, created in January 2010 through a partnership between Samu's GRAU, and the Air Operations Battalion (BOA) of the Military Fire Brigade of Santa Catarina (CBMSC), in Florianópolis. The service features an AS 350B Squirrel model helicopter configured with all advanced life support (SAV) materials and equipment, which is manned by a fire chief pilot, a firefighter copilot, a firefighter crew member, a nurse, and a flight doctor of GRAU.

\section{Population and sample}

To determine the size of the sample of patients that would be served with the protocol, the number of patients treated with some type of trauma, retrieved and transported with life by the aircraft AS 350B Squirrel in the period from September 1, 2011 to August 31, 2012 was used, which reached a total of 130 patients. Sample calculation was executed using a statistical teachinglearning computer program (SEstatNet), with a \pm 5 margin of error and a 95\% confidence level, with a sample of 97 patients. Sampling was non-probabilistic and sequential.

\section{Inclusion and exclusion criteria}

Inclusion criteria were: patients with at least 16 years of age, of both sexes, who were traumatized, rescued, cared for and transported by the aeromedical service aircraft. The reference hospitals consider as adults those persons over the age of 15, which justifies the minimum age of patients. It is considered trauma due to intentional or unintentional causes. Intentional trauma is associated with acts of interpersonal or self-directed violence, in which homicides, suicides and violence between spouses are included. Unintentional trauma has among its causes: collisions of vehicles, trampling, drownings, falls, electric shocks, stings of venomous animals, exogenous intoxications, and burns ${ }^{(12)}$. Patients already dead at the scene and those attended by clinical demands such as infarction, stroke and seizures were excluded.

\section{Study protocol}

The six nurses of the aeromedical service participated in the implementation of the nursing care protocol for patients with trauma. The nurses were given a folder with the protocol, the inclusion and exclusion criteria of the patients for the study, as well as two instruments: one related to the profile of the patients; and a structured checklist with all care validated in the protocol, designed to verify and record the performance or non-performance 
Implementation of the protocol of nursing care in trauma in aeromedical service Schweitzer G, Nascimento ERP, Malfussi LBH, Hermida PMV, Nascimento KC, Moreira AR.

of the care. In case of non-performance, the nurse should note the respective reason, being the options: forgetfulness, not knowing how to do, not agreeing with the protocol, lack of resource, lack of time, or the care does not apply to the patient's condition. The protocol consists of 106 cares, organized in 79 pre-flight cares, 25 during and two after-flight care procedures ${ }^{(6)}$.

One of the researchers explained the completion of the checklist for each nurse, followed each of them in their first record and was available for any doubts that occurred during the data collection. The same nurses participated in the construction of the protocol.

\section{Data analysis and statistics}

The data recorded in the checklist were organized in a spreadsheet in Excel $^{\circ} 2007$ software and analyzed using descriptive statistics.

\section{RESULTS}

As for the characteristics of the professionals participating in the protocol implementation $(n=6,100.0 \%)$, those who were female $(n=5,83.3 \%)$, aged between 31 and 45 years $(n=4,66.7 \%)$, with a mean of 31.8 years $(S D=1.9)$ (Table 1$)$. Of the 97 patients attended by the aeromedical service, men $(\mathrm{n}=$ $78,80.4 \%$ ), aged 16 to 30 years ( $\mathrm{n}$ $=46,47.4 \%$ ) predominated. The average age of the patients was 37.6 years $(S D=16.1)$.

It was evidenced that, of the 106 nursing care procedures included in the protocol, 59 (55.7\%) were executed. Considering all the care executed $(n=6,107)$ in the 97 patients before, during and after the flight, each patient received on average 63 care procedures.

Table 2 shows that the amount of care executed before $(n=4,435)$ during ( $n=1,480)$ and after the flight $(n=192)$ prevailed when compared to the number of care procedures not executed at each of these care moments. Frequency was 149,124 and two care procedures executed, respectively. The care procedure which preceded the flight was the most accomplished; however, these also correspond to most of the protocol.

Of the 79 pre-flight nursing care contemplated in the protocol, 33 were not executed in at least one service, namely: avoid leaving the pulse oximeter exposed to sunlight $(n=22)$; using the capnograph $(n=18)$; placing the pressurizer or syringe pump
Table 1 - Characteristics of the nurses $(n=6)$ and the patients $(n=97)$ participating in the study, Florianópolis, Santa Catarina, Brazil, 2013-2014

\begin{tabular}{|c|c|c|c|c|}
\hline Characteristics of the Nurses & $\mathbf{n}$ & $\%$ & Average & SD \\
\hline Age Bracket & & & 31.8 & 1.9 \\
\hline $16-30$ & 2 & 33.3 & & \\
\hline $31-45$ & 4 & 66.7 & & \\
\hline $46-60$ & - & - & & \\
\hline$\geq 61$ & - & - & & \\
\hline Total & 6 & 100.0 & & \\
\hline \multicolumn{5}{|l|}{ Gender } \\
\hline Male & 1 & 16.7 & & \\
\hline Female & 5 & 83.3 & & \\
\hline Total & 6 & 100.0 & & \\
\hline Characteristics of patients & $\mathbf{n}$ & $\%$ & Average & SD \\
\hline Age Bracket & & & 37.6 & 16.1 \\
\hline $16-30$ & 46 & 47.4 & & \\
\hline $31-45$ & 23 & 23.7 & & \\
\hline $46-60$ & 18 & 18.6 & & \\
\hline$\geq 61$ & 10 & 10.3 & & \\
\hline Total & 97 & 100.0 & & \\
\hline \multicolumn{5}{|l|}{ Gender } \\
\hline Male & 78 & 80.4 & & \\
\hline Female & 19 & 19.6 & & \\
\hline Total & 97 & 100.0 & & \\
\hline
\end{tabular}

Note: SD: Standard Deviation.

Table 2 - Nursing care of the protocol, Florianópolis, Santa Catarina, Brazil, 2013-2014

\begin{tabular}{|c|c|c|c|}
\hline Pre-flight care & $\begin{array}{c}\text { Executed } \\
\text { n (\%) }\end{array}$ & $\begin{array}{c}\text { Unexecuted } \\
\text { n (\%) }\end{array}$ & $\begin{array}{c}\text { Not applicable } \\
\text { n (\%) }\end{array}$ \\
\hline Security guidelines for boarding and disembarking & $588(13.2)$ & $8(5.3)$ & $181(6.1)$ \\
\hline Scene evaluation & $347(7.8)$ & $3(2.0)$ & $38(1.3)$ \\
\hline \multicolumn{4}{|l|}{ Primary Evaluation } \\
\hline A) Airway and control of the cervical spine & $181(4.1)$ & $1(0.7)$ & $303(10.2)$ \\
\hline B) Breathing & $514(11.5)$ & $22(14.8)$ & $413(13.9)$ \\
\hline C) Circulation & $713(16.1)$ & $17(11.5)$ & $521(17.5)$ \\
\hline D) Inability & $269(6.1)$ & $2(1.3)$ & $117(4.0)$ \\
\hline E) Exposure and environment & $262(5.9)$ & - & $223(7.4)$ \\
\hline \multicolumn{4}{|l|}{ Secondary evaluation } \\
\hline Principles and examination of parties & $589(13.3)$ & $23(15.4)$ & $346(11.6)$ \\
\hline Other care procedures * & $972(22.0)$ & $73(49.0)$ & $834(28.0)$ \\
\hline Total & $4,435(100.0)$ & $149(100.0)$ & $2,976(100.0)$ \\
\hline \multicolumn{4}{|l|}{ In-flight care } \\
\hline In-Flight Security Guidelines & $686(46.4)$ & $6(4.8)$ & $181(22.2)$ \\
\hline A) Airway and control of the cervical spine & $88(6.0)$ & - & $9(1.1)$ \\
\hline B) Breathing & $131(8.8)$ & $5(4.0)$ & $349(42.7)$ \\
\hline C) Circulation & $93(6.3)$ & $26(20.1)$ & $74(9.0)$ \\
\hline D) Inability & $128(8.6)$ & $24(19.3)$ & $138(16.9)$ \\
\hline E) Exposure and environment & 354 (23.9) & $63(50.9)$ & $67(8.1)$ \\
\hline Total & $1,480(100.0)$ & $124(100.0)$ & $818(100.0)$ \\
\hline \multicolumn{4}{|l|}{ After-Flight Care } \\
\hline Passing of the shift to the nurse & $95(49.5)$ & $2(100.0)$ & - \\
\hline Filling out of the entire information sheet & $97(50.5)$ & - & - \\
\hline Total & $192(100.0)$ & $2(100.0)$ & - \\
\hline \multicolumn{4}{|c|}{$\begin{array}{l}\text { Note: * Other care procedures: checking blood pressure; checking temperature; assessing the occurrence and intensity of pain with numeric scale, } \\
\text { performing Sampla history (symptoms, allergies, medications, medical past, liquids, events); Re-evaluating neurological function; immobilizing } \\
\text { fractures of limbs in the position in which they are found, including the joint above and below the injury site; recognizing the type of fracture: closed } \\
\text { or exposed; use of traction splint in case of fracture offemur; padding the hard splints preventing interior movements; remotion of jewelry and objects } \\
\text { before immobilization; evaluating neuromuscular function beforeand after applying any immobilization; attemptof immobilization of the patient in } \\
\text { the most anatomical position possible: keeping the collar with side cushions on the side regions of the head, spider strap and in rigid board; performing } \\
\text { analgesia, administering antiemetics; conducting survey oro/NG tube: in over } 15 \text {-minute-long flight; performing vesical probe of delay if necessary } \\
\text { when the volume replacement is large or when the flight has more than } 15 \text { minutes or reaches more than 1,870 feet altitude; reassuring the patient } \\
\text { and family members if they are lucid at the crash site; strengthening compressive dressings; identifying orotracheal tube if the cuff is inflated with } \\
\text { water; choosing equipment and materials to be placed in the cabin during the flight. }\end{array}$} \\
\hline
\end{tabular}


in the serum ( $n=18)$; and, if intubated patient, filling the cuff with water $(n=13)$. The main reasons related to the lack of pre-flight care were: forgetfulness ( $n=45)$; lack of resource $(n=42)$ and time $(\mathrm{n}=41)$; and non-agreement with the protocol $(\mathrm{n}=16)$ (Table 3$)$.

Of the 25 nursing care procedures provided for in the protocol to be executed during the flight, 13 were not executed at least once. Protecting ears with ear muffler $(n=55)$; monitoring patient with multiparameter monitor $(n=21)$; and leaving sedation medications by hand $(n=13)$ stood out the most. One after-flight care procedure of the two which constitute the protocol was not executed on two patients: passing the shift to the nurse informing about the care executed (Table 4).

Table 3 - Unexecuted pre-flight nursing care, according to the related reasons, Florianópolis, Santa Catarina, Brazil, 2013-2014

\begin{tabular}{|c|c|c|c|c|c|c|}
\hline \multirow{2}{*}{ Unexecuted pre-flight care } & \multicolumn{6}{|c|}{ Reasons for non-execution } \\
\hline & NF & NK & NA & NR & NT & Total \\
\hline Pilot assistance in landings and departures & - & 5 & - & - & - & 5 \\
\hline Disembarkation with pilot authorization & 2 & - & - & - & - & 2 \\
\hline Asking if the pilot will keep the driven rotors & 1 & - & 2 & - & - & 3 \\
\hline Checking airway permeability and controlling cervical spine with collar & - & - & - & 1 & - & 1 \\
\hline Administration of oxygen with mask or catheter & - & - & - & - & 1 & 1 \\
\hline Filling the cuff with water, If patient is intubated & 7 & - & 4 & - & 2 & 13 \\
\hline Double attachment of the orotracheal tube & 2 & - & 1 & - & 4 & 7 \\
\hline Avoiding leaving the pulse oximeter exposed to sunlight & 9 & - & - & 10 & 3 & 22 \\
\hline Using of capnograph & - & - & - & 18 & - & 18 \\
\hline Execution of the Sampla history & 1 & - & - & 1 & 5 & 7 \\
\hline Immobilization of fractures & - & - & 1 & - & - & 1 \\
\hline Use of traction splint in case of femoral fracture & - & - & - & - & 1 & 1 \\
\hline Padding hard splints inside & - & - & - & 7 & - & 7 \\
\hline Remotion of jewelry and objects before immobilizing & 1 & - & - & - & - & 1 \\
\hline Execution of analgesia & - & - & - & - & 2 & 2 \\
\hline Performing antiemetics & 2 & - & - & - & 2 & 4 \\
\hline Execution of of OGP or NGP, IN & 1 & - & - & - & 2 & 3 \\
\hline Execution of DCR, IN & - & - & - & 1 & 3 & 4 \\
\hline Checking of the carotid pulse & 1 & - & - & - & 1 & 2 \\
\hline Observation of internal bleeding: assessing abdomen and pelvis & 1 & - & - & - & - & 1 \\
\hline Obtention of access to two large caliber venous & - & - & - & 1 & 1 & 2 \\
\hline Use of bandage on puncture dressing & 2 & - & - & - & 2 & 4 \\
\hline Putting the syringe pump or pressurizer into the serum & 3 & - & 8 & 3 & 4 & 18 \\
\hline Evaluating pupils & 2 & - & - & - & - & 2 \\
\hline Seeing / hearing / feeling head & - & - & - & - & 1 & 1 \\
\hline Seeing / hearing / feeling neck & - & - & - & - & 1 & 1 \\
\hline Seeing / hearing / feeling chest & - & - & - & - & 1 & 1 \\
\hline Seeing / hearing / feeling abdomen & 1 & - & - & - & 2 & 3 \\
\hline Immobilization and tilt of rigid board (pregnant) & 1 & - & - & - & - & 1 \\
\hline Reassuring patient and family & - & - & - & - & 2 & 2 \\
\hline Strenghtening of compressive dressings & 1 & - & - & - & - & 1 \\
\hline Identification of OTT, if cuff inflated with water & 5 & - & - & - & - & 5 \\
\hline Choosing equipment and supplies to be placed in the flight deck & 2 & - & - & - & 1 & 3 \\
\hline Total & 45 & 5 & 16 & 42 & 41 & 149 \\
\hline
\end{tabular}

Note: NE-not executed by forgetting; NK-not executed for not knowing how to do; NA - not executed for non-agreement with the protocol; NR - not executed for lack of resources; NT - not executed for lack of time; Sampla-symptoms, allergies, medications, medical past, liquids, events; OGP-orogastric probe; NGP-nasogastric probe; IN-ifnecessary; DCR-delayed removal of urinary catheter; OTT-orotracheal tube.

Table 4 - Nursing care not executed during and after flight, according to the related reasons, Florianópolis, Santa Catarina, Brazil, 2013-2014

\begin{tabular}{|c|c|c|c|c|c|c|}
\hline \multirow{2}{*}{ Unexecuted in-flight care } & \multicolumn{6}{|c|}{ Reasons for non-execution } \\
\hline & NF & NK & NA & NR & NT & Total \\
\hline Keeping materials in the aircraft fixed and well conditioned & - & - & - & 1 & - & 1 \\
\hline Notifying the pilot or crew member if objects that may collide with the aircraft are observed & - & - & - & - & 1 & 1 \\
\hline Knowing flight information to schedule assistance & 1 & - & - & - & - & 1 \\
\hline Use of bacteriological filters for mechanical ventilation or manual resuscitation & 3 & - & - & - & - & 3 \\
\hline Execution of oximetry monitoring and administer $\mathrm{O} 2$ in all patients & - & - & - & - & 1 & 1 \\
\hline Observing signs of pneumothorax & 1 & - & - & - & - & 1 \\
\hline Monitoring patient with multi-parameter monitor & 3 & - & 1 & - & 17 & 21 \\
\hline Keeping serums in pressurizer and syringe pump medications & 3 & - & 1 & - & 2 & 6 \\
\hline Placing sedation medications close & 4 & - & 1 & - & 8 & 13 \\
\hline Watching out for seizures, wearing protective clothing / visors & 7 & - & - & 3 & 2 & 12 \\
\hline Protecting ears with ear muffler & 12 & - & 1 & 40 & 2 & 55 \\
\hline Keeping patient warm & - & - & - & 1 & - & 1 \\
\hline Maintaining the separation between patient and aircraft structure & 1 & - & - & 7 & - & 8 \\
\hline Total & 35 & - & 4 & 52 & 33 & 124 \\
\hline Unexecuted after-flight care & NF & NK & NA & NR & NT & Total \\
\hline Passing of the shift to the nurse informing about the cares executed & - & - & - & 2 & - & 2 \\
\hline Total & - & - & - & 2 & - & 2 \\
\hline
\end{tabular}


The predominant reasons related to the non-performance of care during and after the flight were: lack of resources $(n=54)$; forgetfulness $(n=35)$; and lack of time $(n=33)$. There was no record of care not implemented during the flight related to the fact that the professional did not know how to do the procedure (Table 4).

\section{DISCUSSION}

The data of this study corroborate the statistics evidenced in the literature regarding patient characteristics, with young and male adults being the most affected by trauma ${ }^{(11,13-14)}$.

The nursing care executed before, during and after the flight have stood out in relation to those not executed, which indicates a good adhesion of the nurses to its implementation. The good adhesion may be related to their participation in the construction of the protocol. Researches indicate that involvement of professionals in the development of protocols can positively influence their adherence and implementation ${ }^{(15)}$.

The implementation of care protocols has been widely studied by Nursing ${ }^{(16)}$. The results of its use demonstrate that it is a modern tool, supported by public policies, that supports decision-making by nurses, which allow all professionals to provide standardized care for patient safety, in accordance with technical and scientific principles. Also, care protocols help reducing the distortions acquired in practice, as well as having an educational purpose ${ }^{(17-19)}$.

A study of construction and validation of a nursing care protocol in anesthesia ${ }^{(10)}$ showed that the use of protocols and checklists can help in the detection of errors and negligence in relation to care through proper verification of equipment and materials. The study also shows that its use promote the exchange of information among professionals about the clinical conditions of the patient, which improves their perception about teamwork and prevents harm - aspects which contribute to patient safety.

Therefore, assistance and care protocols, standard operating procedures, among others, are instruments intended to guide health professionals in the care of patients and should be applied in the reality of different health care settings to promote quality care ${ }^{(20-21)}$. In the aerospace environment it is necessary a thorough evaluation of the patient for a correct stabilization of the rescue, based on accepted protocols and the fundamentals of altitude physiology ${ }^{(22)}$. In this sense, the implementation of this protocol contributes to an organized and systematic approach to care, searching for a better prognosis.

In this study, the primary evaluation of the circulation was the most executed pre-flight care procedure constituting the protocol. In trauma patients, assessment is the basis of treatment, due to possible complications. Successful assessment and intervention requires extensive scientific knowledge about the physiology of trauma and a well-developed treatment plan that is executed quickly and efficiently ${ }^{(12)}$.

The primary evaluation of the circulation aims to control hemorrhages. It is a fundamental care, since serious damages occur, while the hemorrhage is not controlled and the tissue oxygenation is reduced due to inadequate perfusion, which decrease the patient's survival ${ }^{(12,23)}$. Thus, for a successful treatment of patients with trauma, there is a decisive time called "golden period", which ranges from the occurrence of trauma to the definitive treatment of hemorrhage ${ }^{(12)}$.
The most accomplished in-flight care was the security guidelines. This finding is corroborated by the literature. Security guideliness are understood as indispensable actions to maximize flight security for the team, the aeromedical crew and the airborne patient ${ }^{(24)}$. A study reporting the experience of nurses in air transport ${ }^{(25)}$ presents security guidelines as a key element in the care of critically ill patients on aircraft, as this care avoids the occurrence of unexpected events and critical situations during flight.

"Filling out the entire answer sheet" stood out among executed after-flight care procedures. On the other hand, a research study on the implementation of a protocol of infection of the urinary tract in an intensive care unit showed that the filling and annotations of professionals are often considered fragile ${ }^{(26)}$.

When applying the care protocol, nurses should be careful not to underestimate their capacity for clinical judgment, considered an essential step in decision-making for effective care. This infers that the nurses in this study practice this judgment, considering the frequency of care classified as "not applicable", response that may be related, for example, to the inadequacy of care to the type of trauma treated. The professional judgment in apllying the protocol is also supported by a Dutch study, but reasons such as standardization and uniformity of care justify the focus on adherence ${ }^{(27)}$.

The care procedures that were not carried out had as main reasons: forgetfulness, lack of resource and time, and nonagreement with the protocol. Comparatively, in the scenario of the emercengy care units, the non-compliance of the national patient safety protocols was evidenced, exposing the patients to preventable adverse events ${ }^{(17)}$. In terrestrial mobile pre-hospital care, adherence to the protocol was below ideal, although nurses reported high adherence. Protocol-related factors, such as its complexity, support for diagnosis and treatment, and the relation of the protocol to patient outcomes seem to influence this adherence ${ }^{(28)}$. Thus, there is a gap between protocols and clinical practice, which may lead to inadequate care.

The results also revealed that "protecting the ears with ear muffler" was not executed because of lack of this resource. Intense noise causes discomfort and, if the patient is lucid, values above 85 decibels (dB) are considered harmful to the ears ${ }^{(12)}$. Long flights can cause headache, dizziness, fatigue, visual disturbances, and temporary or permanent damage to the ear - since aeronautical noise varies between $110-130 \mathrm{~dB}^{(12,24)}$. Forgetting this care procedure may be related to short flights or to the use of cushions and cervical collar in trauma patients, since these resources suppress helicopter noise.

Another care procedure not executed was "avoid leaving the pulse oximeter exposed to sunlight," which was motivated by lack of resource, time and forgetfulness. In public roads, under the sun, it is impossible to cover this device. Also, because they are prehospital care procedures, the time factor is prioritized, leading to forgetfulness of care execution. However, one study explains that the oximeter uses two wavelengths to measure oxygen saturation (SpO2, which can be produced by different ambient light sources, leading to false $\mathrm{SpO} 2$ readings, which is not desirable ${ }^{(29)}$.

Regarding "monitoring the patient with a multi-parameter monitor during the flight, "the main factor for non-execution was the time, which can be reduced to assistances that require short flights, leading the nurse to use only the portable oximeter. 
Implementation of the protocol of nursing care in trauma in aeromedical service Schweitzer G, Nascimento ERP, Malfussi LBH, Hermida PMV, Nascimento KC, Moreira AR.

Despite that, it is emphasized that the multiparameter monitor allows continuous hemodynamic monitoring of different vital parameters of the patient: blood pressure, heart rate and oxygen saturation. At the impossibility of hearing the blood pressure due to the intense noise inside the helicopter ${ }^{(22,25)}$, monitoring the patient using the multiparameter monitor is relevant.

\section{Study limitations}

The deficiencies in the implementation of the protocol evidenced in this study are related to individual, organizational and to protocol characteristics, such as forgetfulness, lack of resource and non-agreement of the professional with the protocol, respectively, which requires reflection and improvement strategies. Knowing the flight time of the assistances could confirm or reject the justification that some nursing care procedure of the protocol was not executed due to the duration of the flights, with reduced time of assistance by the aeromedical service.

\section{Contributions to the field of nursing}

This study indicates that the implementation of the care protocol contributed to systematizing nursing care to trauma patients assited by an aero-medical service, directing to clinical practice, which may stimulate its application in similar services. It also revealed barriers in the implementation of the protocol, which should be discussed among nurses and service managers in order to overcome them. In addition, the research adds knowledge to aerospace nursing, especially regarding the use of protocols to ensure quality care.

\section{CONCLUSION}

It was evidenced that, although the majority of the nursing care procedures of the protocol was implemented by the nurses of the aero-medical service. The nursing care not executed, mainly due to lack of resources, time and forgetfulness, compromise the quality of care, which requires the management of the service to offer a greater incentive to nurses and adequate resources for its effectiveness in clinical practice.

\section{FUNDING}

This study had the support of the Coordination for the Improvement of Higher Education Personnel - Brazil (CAPES) - Financing Code 001.

\section{REFERENCES}

1. Correia PMAM, Silva NFD, Pereira MAP, Freire AMI, Linhares CS, Huygens PGJ. Liver harvesting from the donor to the transplant: a proposed protocol for nurses. Esc Anna Nery [Internet]. 2016 [cited 2018 Jan 23];20(1):2038-47. Available from: http://www.scielo.br/pdf/ean/ v20n1/1414-8145-ean-20-01-0038.pdf

2. Ministério da Saúde (BR). Secretaria de Ciência, Tecnologia e Insumos Estratégicos, Gestão e Incorporação de Tecnologias em Saúde. Diretrizes metodológicas: elaboração de diretrizes clínicas [Internet]. Brasília, DF; 2016 [cited 2018 May 22]. Available from: http://conitec. gov.br/images/Relatorios/2016/Diretrizes_Metodologicas_WEB.pdf

3. Rodrigues EM, Nascimento RG, Araújo A. Prenatal care protocol: actions and the easy and difficult aspects dealt by Family Health Strategy nurses. Rev Esc Enferm USP [Internet]. 2011 [cited 2018 Jan 22];45(5):1041-47. Available from: http://www.scielo.br/pdf/reeusp/v45n5/ en_v45n5a02.pdf

4. Holleran RS. Air and surface transport nurses association. St. Louis: Mosby Elsevier; 2010.

5. Schweitzer G, Nascimento ERP, Nascimento KC, Moreira AR, Amante LN, Malfussi LBH. Emergency interventions for air medical services trauma victims. Rev Bras Enferm [Internet]. 2017 [cited 2018 May 31];70(1):48-54. Available from: http://www.scielo.br/pdf/reben/v70n1/ en_0034-7167-reben-70-01-0054.pdf

6. Schweitzer G. Validação de um protocolo de cuidados de enfermagem a pacientes vítimas de trauma no ambiente aeroespacial [tese]. Florianópolis: Programa de Pós-Graduação em Enfermagem, Universidade Federal de Santa Catarina; 2015. 221 p.

7. Francke AL, Smit MC, de Veer AJE, Mistiaen P. Factors influencing the implementation of clinical guidelines for health care professionals: a systematic meta-review. BMC Med Inform Decis Mak [Internet]. 2008 [cited 2018 Aug 19];8:38. Available from: https:// bmcmedinformdecismak.biomedcentral.com/track/pdf/10.1186/1472-6947-8-38

8. Chan WV, Pearson TA, Bennett GC, Cushman WC, Gaziano TA, Gorman PN, et al. ACC/AHA special report: clinical practice guideline implementation strategies: a summary of systematic reviews by the NHLBI Implementation Science Work Group: a report of the American College of Cardiology/American Heart Association Task Force on Clinical Practice Guidelines. J Am Coll Cardiol [Internet]. 2017 [cited 2018 Aug 19];69(8):1076-92. Available from: https://www.sciencedirect.com/science/article/pii/S0735109716368322?via\%3Dihub

9. Pimenta CAM, Pastana ICASS, Sichieri K, Solha RKT, Souza W. Guia para construção de protocolos assistenciais de enfermagem [Internet]. São Paulo: Coren-SP; 2017 [cited 2018 May 5]. Available from: http://portal.coren-sp.gov.br/sites/default/files/Protocolo-web.pdf

10. Lemos CS, Poveda VB, Peniche ACG. Construction and validation of a nursing care protocol in anesthesia. Rev Latino-Am Enfermagem [Internet]. 2017 [cited 2018 Jun 4];25:e2952. Available from: http://www.scielo.br/pdf/rlae/v25/pt_0104-1169-rlae-25-e2952.pdf

11. Cardoso RG, Francischini CF, Ribera JM, Vanzetto R, Fraga GP. Helicopter emergency medical rescue for the traumatized: experience in the metropolitan region of Campinas, Brazil. Rev Col Bras Cir [Internet]. 2014 [cited 2018 May 31];41 (4):236-44. Available from: http://www. scielo.br/pdf/rcbc/v41n4/0100-6991-rcbc-41-04-00236.pdf 
Implementation of the protocol of nursing care in trauma in aeromedical service

12. National Association of Emergency Medical Technicians. PHTLS: atendimento pré-hospitalar ao traumatizado. 8a ed. Burlington: Jones \& Bartlett Learning; 2016.

13. Cover DP, Nunes EAB, Carvalho KM. Mortality in traffic accidents in Piauí: characterization of cases in the biennium 2012-2013. Rev Uningá [Internet]. 2018 [cited 2018 Aug 21];49(1):12-9. Available from: http://revista.uninga.br/index.php/uninga/article/view/1309/928

14. Geiger LSC, Chavaglia SRR, OhI RIB, Barbosa MH, Tavares JL, Oliveira ACD. Trauma from traffic accidents after implementation of Law no. 11.705 - "Dry Law". Rev Min Enferm [Internet]. 2018 [cited 2018 Oct 11];22:e-1072. Available from: http://www.reme.org.br/artigo/ detalhes $/ 1210$

15. Ebben RHA, Vloet LCM, Schalk DMJ, Groot JAJM, van Achterberg T. An exploration of factors influencing ambulance and emergency nurses' protocol adherence in the Netherlands. J Emerg Nurs [Internet]. 2014 [cited 2018 Jun 3];40(2):124-30. Available from: https://www.jenonline. org/article/S0099-1767(12)00443-6/pdf

16. Sales CB, Bernardes A, Gabriel CS, Brito MFP, Moura AA, Zanetti ACB. Standard Operational Protocols in professional nursing practice: use, weaknesses and potentialities. Rev Bras Enferm [Internet]. 2018 [cited 2018 Jun 4];71(1):126-34. Available from: http://www.scielo.br/pdf/ reben/v71n1/0034-7167-reben-71-01-0126.pdf

17. Paixao DPSS, Batista J, Maziero ECS, Alpendre FT, Amaya MR, Cruz EDA. Adhesion to patient safety protocols in emergency care units. Rev Bras Enferm [Internet]. 2018 [cited 2018 Aug 21];71(Suppl 1):577-84. Available from: http://www.scielo.br/pdf/reben/v71s1/0034-7167reben-71-s1-0577.pdf

18. Almeida ML, Segui MLH, Maftum MA, Labronici LM, Peres AM. Management tools used by nurses in decision-making within the hospital context. Texto Contexto Enferm [Internet]. 2011 [cited 2018 Jun 4];20(Spe):131-7. Available from: http://www.scielo.br/pdf/tce/v20nspe/ v20nspea17.pdf

19. Cunningham CA, Gervais LB, Mazurak VC, Anand V, Garros D, Crick K, et al. Adherence to a nurse-driven feeding protocol in a pediatric intensive care unit. JPEN J Parenter Enteral Nutr [Internet]. 2017 [cited 2018 Aug 22];42(2):327-34. Available from: https://onlinelibrary.wiley. com/doi/epdf/10.1177/0148607117692751

20. Machado RC, Gironés P, Souza AR, Moreira RSL, Jakitsch CB, Branco JNR. Nursing care protocol for patients with a ventricular assist device. Rev Bras Enferm [Internet]. 2017 [cited 2018 May 26];70(2):335-41. Available from: http://www.scielo.br/pdf/reben/v70n2/0034-7167reben-70-02-0335.pdf

21. Vasconcelos JMB, Caliri MHL. Nursing actions before and after a protocol for preventing pressure injury in intensive care. Esc Anna Nery [Internet]. 2017 [cited 2018 Jan 21];21(1):e20170001. Available from: http://www.scielo.br/pdf/ean/v21n1/en_1414-8145-ean-2101-e20170001.pdf

22. Gentil RC. Transporte Aéreo: o diferencial na assistência de enfermagem. In: Malagutti W, Caetano KC. Transporte de pacientes: a segurança em situações críticas. São Caetano do Sul, SP: Editora Yendis; 2015.

23. Stancil SA. Development of a new infusion protocol for austere trauma resuscitations. Air Med J [Internet]. 2017 [cited 2018 Aug 21];36(5):239-43. Available from: https://doi.org/10.1016/j.amj.2017.02.006

24. Reis MCF, Vasconcellos DRL, Saiki J, Gentil RC. Os efeitos da fisiologia aérea na assistência de enfermagem ao paciente aerorremovido e na tripulação aeromédica. Acta Paul Enferm. 2000;13(2):16-25.

25. Senften J, Engstorm A. Critical care nurses' experiences of helicopter transfers. Nurs Crit Care [Internet]. 2013 [cited 2018 Jun 4];20(1):25-33. Available from: https://onlinelibrary.wiley.com/doi/epdf/10.1111/nicc.12063

26. Miranda AL, Oliveira ALL, Nacer DT, Aguiar CAM. Results after implementation of a protocol on the incidence of urinary tract infection in an intensive care unit. Rev Latino-Am Enfermagem [Internet]. 2016 [cited 2018 Jun 4];24:e2804. Available from: http://www.scielo.br/pdf/rlae/ v24/0104-1169-rlae-24-02804.pdf

27. Ebben RHA, Vloet LCM, Grunsven PM, Breeman W, Goosselink B, Lichtveld RA, et al. Factors influencing ambulance nurses' adherence to a national protocol ambulance care: an implementation study in the Netherlands. Eur J Emerg Med [Internet]. 2014 [cited 2018 Jun 4];22(3):199-205. Available from: https://www.ncbi.nlm.nih.gov/pmc/articles/PMC4410961/pdf/mej-22-199.pdf

28. Ebben RHA, Vloet LCM, Verhofstad MHJ, Meijer S, Groot JAJM, van Achterberg T. Adherence to guidelines and protocols in the prehospital and emergency care setting: a systematic review. Scand J Trauma Resusc Emerg Med [Internet]. 2013 [cited 2018 Jun 3];21:9. Available from: https://sjtrem.biomedcentral.com/track/pdf/10.1186/1757-7241-21-9

29. Jubran A. Pulse oximetry. Crit Care [Internet]. 2015. [cited 2018 Jun 2];19(1):272. Available from: https://www.ncbi.nlm.nih.gov/pmc/articles/ PMC4504215/pdf/13054_2015_Article_984.pdf 